\title{
RELATIONS DIVERSITY AND PHYSICAL SPATIAL FUNCTIONAL COMPONENT IN HIGHWAY CORRIDOR AND CORRIDOR PASSAGEWAY KOPO STONES DOWNTOWN BANDUNG SOUTHERN
}

\author{
${ }^{1}$ Faridah Zakiyah. ${ }^{2}$ Anindhita N. Sunartio, S.T., M.T. \\ ${ }^{1}$ Student in the Bachelor's (S-1) Study Program in Architecture \\ at Parahyangan Catholic University \\ ${ }^{2}$ Senior lecturer in the Bachelor's (S-1) Study Program in Architecture \\ at Parahyangan Catholic University
}

\begin{abstract}
Having been an autonomous region since 1906, Bandung has experienced continuous expansion. One factor pushing this development was the construction of a road network connecting Bandung with its surrounding towns, yielding a variety of spatial and functional physical elements in urban space. This research study examines the architectural development of the southern part of Bandung, located on Jalan Raya Kopo and Jalan Terusan Buah Batu from 1996 until 2015 by analyzing the transformation that occurred, using the typo-morphological method, and by determining the correlation between the functional elements (land use or exploitation and the spatial-physical component of buildings and land parcels known as kaveling of their scope (height, mass lay-out, area width and type of lot). The tendency of the the area's expansion in each of the street corridors can be analyzed through determining the correlation between these components covering the variety and dominant character or features observed. Jalan Raya Kopo shows a tendency toward a commercial trade-bound function whose mass type consists of one storey situated on the land parcel on the roadside in the middle of small lots. On the other hand, the extension of Jalan Terusan Buah Batu shows a functional tendency toward mixed use featuring a twostoried building mass on a land parcel on the roadside positioned in the middle of small lots. A change has been discernible in the actual planning of the spatial pattern from a purely residential area into a merger between commercial or industrial occupancy, in addition to the increasing density of the area and its soaring skyline.
\end{abstract}

Keywords: Urban architecture, physical, spatial, street corridor

\section{HUBUNGAN KERAGAMAN KOMPONEN FUNGSIONAL DAN FISIK SPASIAL PADA KORIDOR JALAN RAYA KOPO DAN KORIDOR JALAN TERUSAN BUAH BATU -KOTA BANDUNG BAGIAN SELATAN}

\author{
${ }^{1}$ Faridah Zakiyah. ${ }^{2}$ Anindhita N. Sunartio \\ ${ }^{1}$ Mahasiswi S1 Program Studi Arsitektur Universitas Katolik Parahyangan. \\ ${ }^{2}$ Dosen Pembimbing S1 Program Studi Arsitektur Universitas Katolik Parahyangan.
}

${ }^{1}$ Corresponding author: faridahzakiyah@icloud.com 
Abstrak- Bandung sebagai daerah otonom pada sejak tahun 1906 terus mengalami perkembangan. Salah satu pemicunya adalah adanya pembangunan struktur jalan yang menghubungkan Kota Bandung dengan kota-kota disekitarnya dan memunculkan keragaman elemen fisik spasial dan fungsional pada ruang kota. Penelitian ini mempelajari perkembangan arsitektur Kota Bandung bagian Selatan pada Jl. Raya Kopo dan Jl. Terusan Buah Batu dalam periode 1996 hingga 2015, menganalisa transformasi yang terjadi dengan metode tipo-morfologi dan mencari kolerasi antara komponen fungsi (tata guna lahan) dan komponen fisik spasial bangunan serta kapling pelingkupnya (ketinggian, tata massa, luas dan tipe kapling). Kecenderungan perkembangan kawasan pada masing - masing koridor jalan dapat di analisa melalui korelasi antar komponen fisik spasial dan fungsional meliputi keragaman dan dominasi yang terjadi. Pada Jl. Raya Kopo kecenderungan yang terjadi adalah fungsi perdagangan dengan tipe massa tunggal 1 lantai pada kapling tepi jalan yang posisinya di tengah dengan luasan kapling kecil. Pada Jl. Terusan Buah Batu kecenderungan yang terjadi adalah fungsi mixed use dengan tipe massa tunggal 2 lantai pada kapling tepi jalan yang posisinya di tengah dengan luasan kapling kecil. Terlihat perubahan rencana pola tata ruang dari kawasan hunian menjadi gabungan antara komersial hunian dan industri serta densitas kawasan yang semakin padat dengan perubahan skyline kawasan menjadi lebih tinggi.

Kata kunci: Arsitektur kota, fisik, spasial, koridor jalan

\section{PENDAHULUAN}

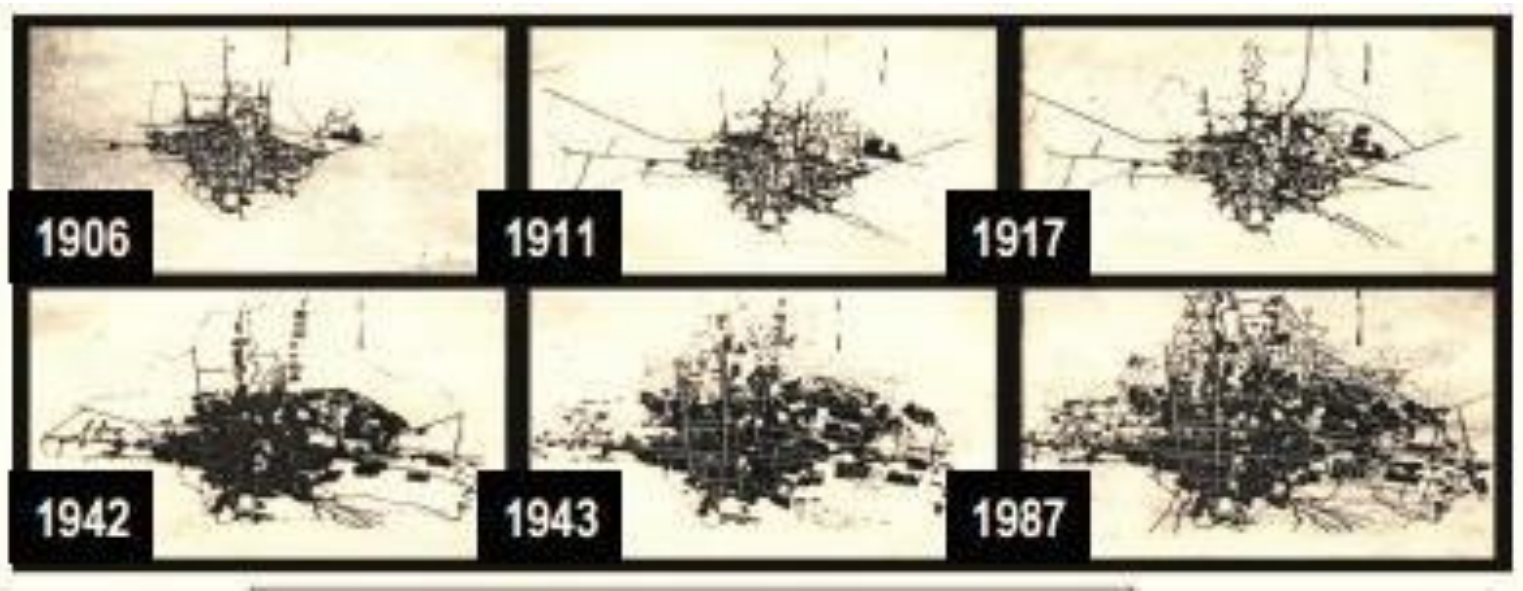

Figur 1. Peta perluasan Kota Bandung Tahun 1906 - 1987

(Sumber : Semerbak Bunga di Bandung Raya tahun 1986)

Dari sejak didirikannya pada tahun 1906 hingga sekarang ini Kota Bandung telah beberapa kali mengalami perluasan wilayah. Luas wilayah kota yang tadinya hanya \pm 900 Ha kini telah meluas menajadi $\pm 17.000 \mathrm{Ha}$. Dengan meluasnya wilayah administratif kota maka aktivitas atau kegiatan warganya lambat laun akan menyebar ke wilayah yang baru ditambahkan. Wujud kota Bandung dari sejak awal berdiri hingga saat ini terus mengalami transformasi dan morfologi yang terbentuk dipengaruhi oleh berbagi faktor pemicu, salah satu diantaranya adalah perkembangan struktur jalan. Pada kawasan Kota Bandung Bagian Selatan, terdapat 3 struktur jalan utama yaitu Jl. Raya Kopo, Jl. Moch. Toha, dan Jl. Terusan Buah Batu yang menghubungkan Bandung denga kota - kota di sekitarnya.

Jl. Raya Kopo merupakan jalur penghubung Bandung - Soreang - Ciwidey yang menjadi jalur transportasi utama untuk mengirim hasil bumi dari daerah selatan Kota Bandung.Jl. Moch. 
Toha menghubungkan Kota Bandung - Banjaran - Pangalengan dan merupakan jalur yang digunakan untuk mengirim hasil perkebunan dan pertaian dari pangalengan menuju Kota Bandung. Sedangkan Jl. Terusan Buah Batu menghubungkan Kota Bandung - Ciparay - Majalaya dan merupakan jalur yang digunakan untuk mengirim komoditas dari Majalaya berupa produk industri tekstil menuju Kota Bandung. Kegiatan mobilisasi hasil bumi dan komoditas tersebut memicu perkembangan aktivitas di sekitar koridor jalan.

Hal ini membuat wujud kota terus mengalami perubahan mengikuti perkembangan tersebut secara dinamis. Hingga beberapa tahun belakangan ini transformasi yang terjadi di wilayah pinggiran Kota Bandung semakin terasa berkembang secara signifikan. Perubahan wujud kota yang dimaksud meliputi, perubahan fisik spasial beserta elemen - elemen pembentuk fisik kota itu sendiri, dan perubahan yang sifatnya non-fisik seperti fungsi dan aktivitas yang diwadahinya. Dari 3 struktur jalan yang yang ada, terdapat 2 koridor jalan yang secara fisik mengalami perubahan yang signifikan yaitu Jl. Raya Kopo dan J1. Terusan Buah Batu.

Fokus bahasan yang akan di kaji pada studi ini adalah perkembangan arsitektur kota Bandung dari tahun 1996 sampai 2015, ragam komponen fungsional (tata guna lahan) dan komponen fisik spasial (meliputi ketinggian bangunan, tata massa bangaun, tipe bentuk dan luasan kapling) yang terjadi pada tahun 2015, serta hubungan antar komponen dan kecenderungan yang mempengaruhi wujud ruang Kota Bandung bagian selatan khususnya pada koridor Jl. Raya Kopo dan Jl. Terusan Buah Batu.

\section{KAJIAN TEORI}

\subsection{METODE PENELITIAN}

Pendekatan terhadap perkembangan arsitektur kota menggunakan metode analisis morfologi. Menganalisa transformasi yang terjadi pada objek beserta keseluruhan konteksnya. Pembahasan transformasi tersebut ditinjau dengan membaca kota atau kawasan secara sinkronik diakronik.

Pendekatan terhadap ragam dan kecenderungan fisik spasial dan fungsional menggunakan metode analisis tipologi dengan cara mengklasifikasikan massa bangunan berdasarkan aspek fisik spasial (terkait massa bangunan) dan aspek non-fisik (fungsional) untuk melihat keragaman tipe dan varian dari keseluruhan elemen fisik spasial dan fungsional yang ada.

Untuk melihat hubungan atau kolerasi antara aspek fisik spasial (terkait massa bangunan) dan aspek non-fisik (fungsional) digunakan pendekatan statistik korelasi dengan alat bantu program SPSS (Statistical Package for the Social Sciences).

Dari analisa tersebut akan didapat suatu gambaran arsitektur Kota Bandung bagian selatan khususya pada koridor J1. Raya Kopo dan Jl. Terusan Buah Batu berdasarkan arah kecenderungan perkembangannya beserta ragam tipe fisik dan fungsional yang ada pada kedua kawasan tersebut.

\section{ANALISIS}

\subsection{PERKEMBANGAN}

Jika dilihat dari perkembangan struktur jalannya JL. Raya Kopo dan Jl. Terusan Buah Batu merupakan jalan kolektor primer yang menghubungkan antara pusat kota dengan kota - kota di 
sekitar Bandung. J1. Raya Kopo menghubungkan pusat perdagangan Kota Bandung dengan Kota Soreang yang merupakan Ibu Kota Kabupaten Bandung. Jl. Terusan Buah Batu menghubungkan kawasan pusat Kota bandung dengan Kota Majalaya yang merupakan sentra industri.

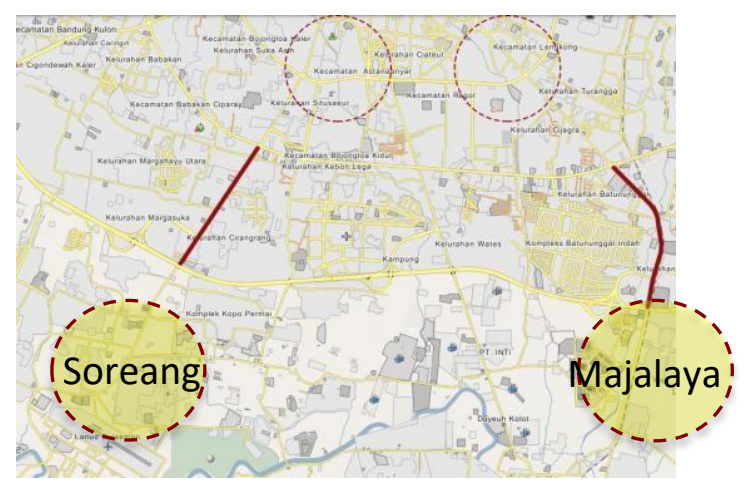

Figur 2. Peta J1. Raya Kopo dan J1. Terusan Buah Batu

Dari segi perturan yang berlaku terjadi perubahan pola tata ruang. Dalam RTRW tahun 2001-2010 kawasan di sekitar koridor Jl. Raya Kopo dan Jl. Terusan Buah Batu secara garis besar direncanakan sebagai kawasan hunian dan area perdaganagan pada simpul pertemuan dengan J1 Soekarno Hatta. Dalam RTRW tahun 2011-2031 rencana tersebut bergeser menjadi kawasan perdagangan pada koridor jalan dan kawasan hunian pada kantung.
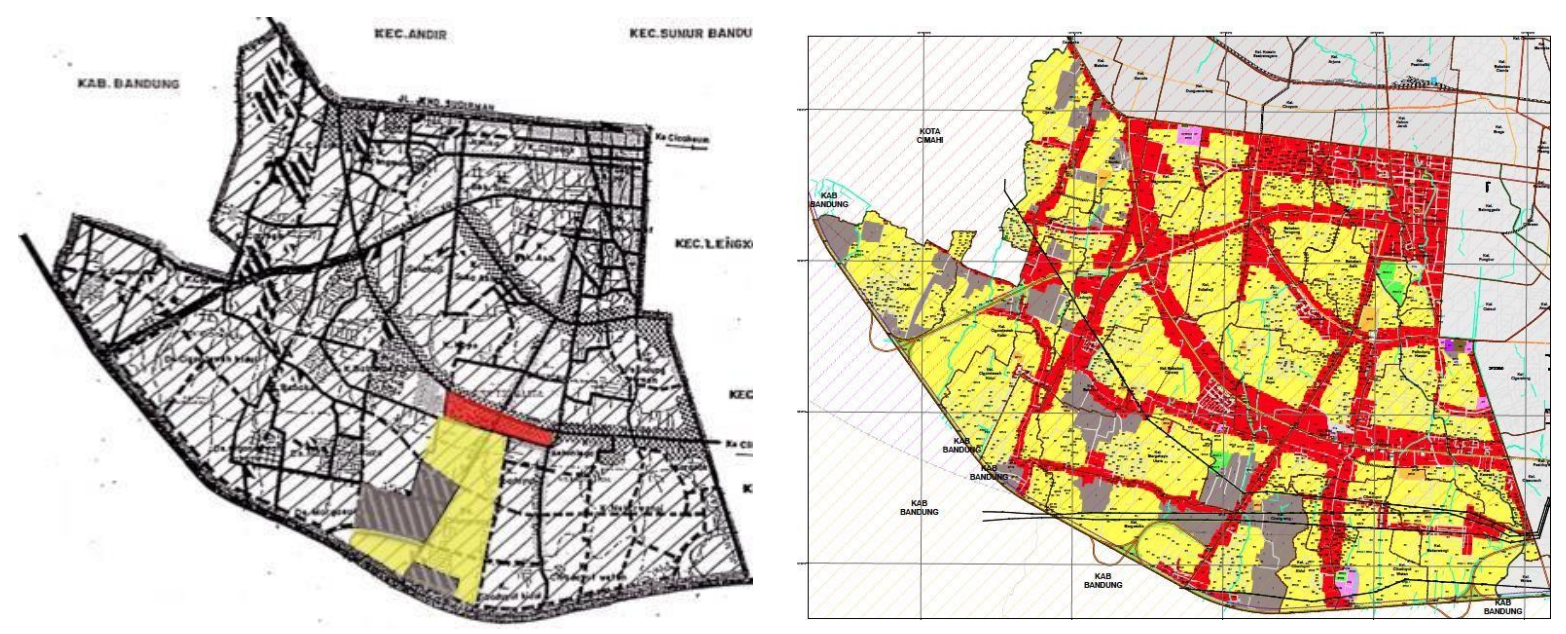

Figur 3. Pola tata ruang koridor J1. Raya Kopo RDTR Kawasan Tegallega tahun 20032010

Figur 4. Pola tata ruang koridor Jl. Raya Kopo berdasarkan berdasarkan RDTR Kawasan Tegallega tahun 2015-

2035 


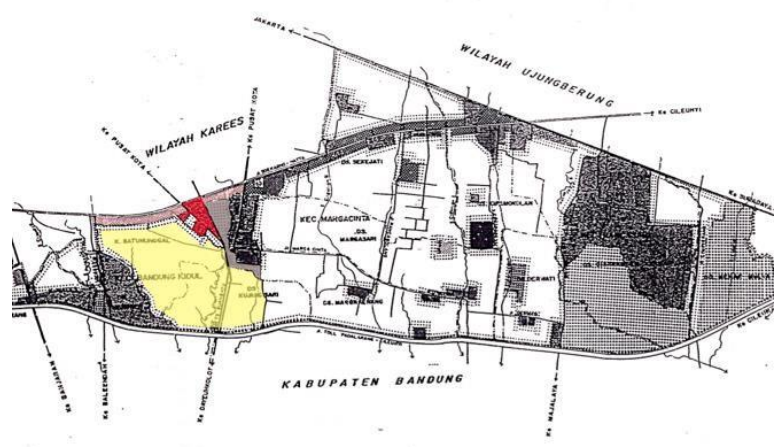

Figur 5. Pola tata ruang koridor Jl. Terusan Buah Batu berdasarkan RDTR Kawasan Gedebage tahun 2003-2010

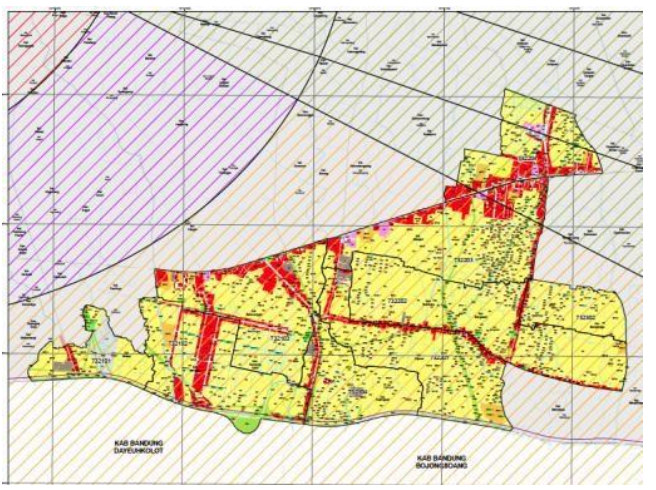

Figur 6. Pola tata ruang koridor Jl. Terusan Buah Batu berdasarkan RDTR Kawasan Gedebage tahun 2015-2035

Perkembangan tersebut juga berpengaruh terhadap perubahan fisik yang terjadi pada kawasan. Dilihat dari perubhan blok massa yang mengalami penambahan sehingga densitas kawasan menjadi lebih padat juga mulai bermunculan masa - massa dengan skala yang berbeda, yaitu lebih besar atau lebih tinggi.
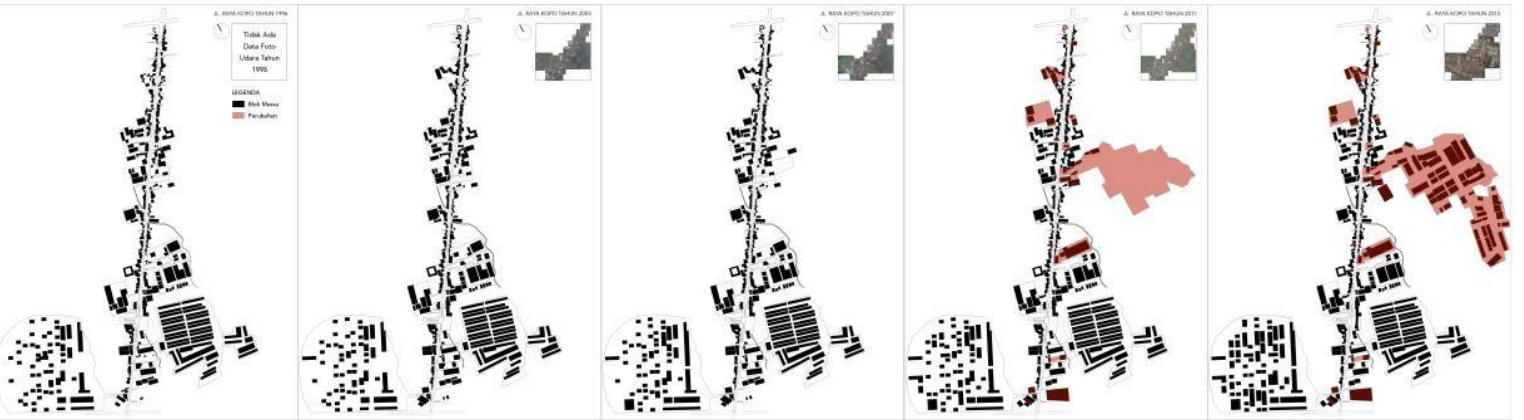

Figur 7. Peta perkembangan blok massa Jl. Raya Kopo tahun 1996 - 2015

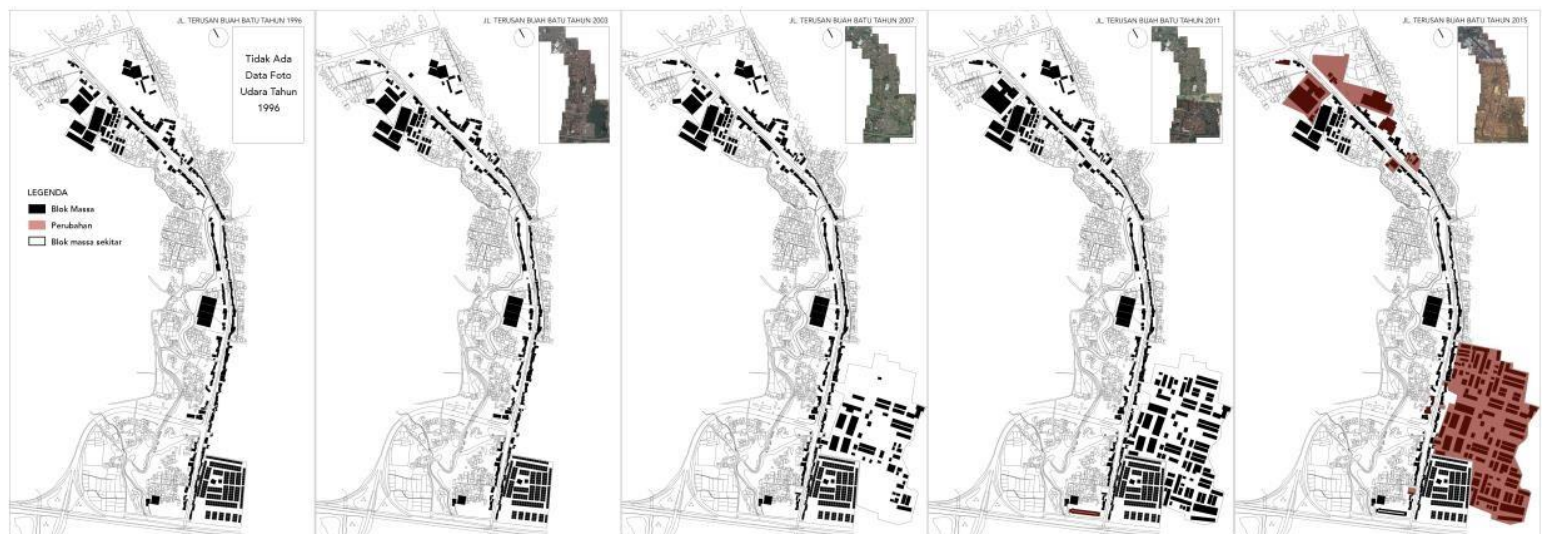

Figur 8. Peta perkembangan blok massa Jl. Terusan Buah Batu tahun 1996 - 2015 
Pada keuda koridor jalan terdapat dua titik yang paling berkembang atau paling banyak mengalami perubahan yaitu pada segmen jalan dekat akases keluar masuk Jalan Tol dan segmen dekat persimpangan Jl. Soekarno Hatta pada Jl. Terusan Buah Batu, dan segmen tengah pada Jl. Raya Kopo.

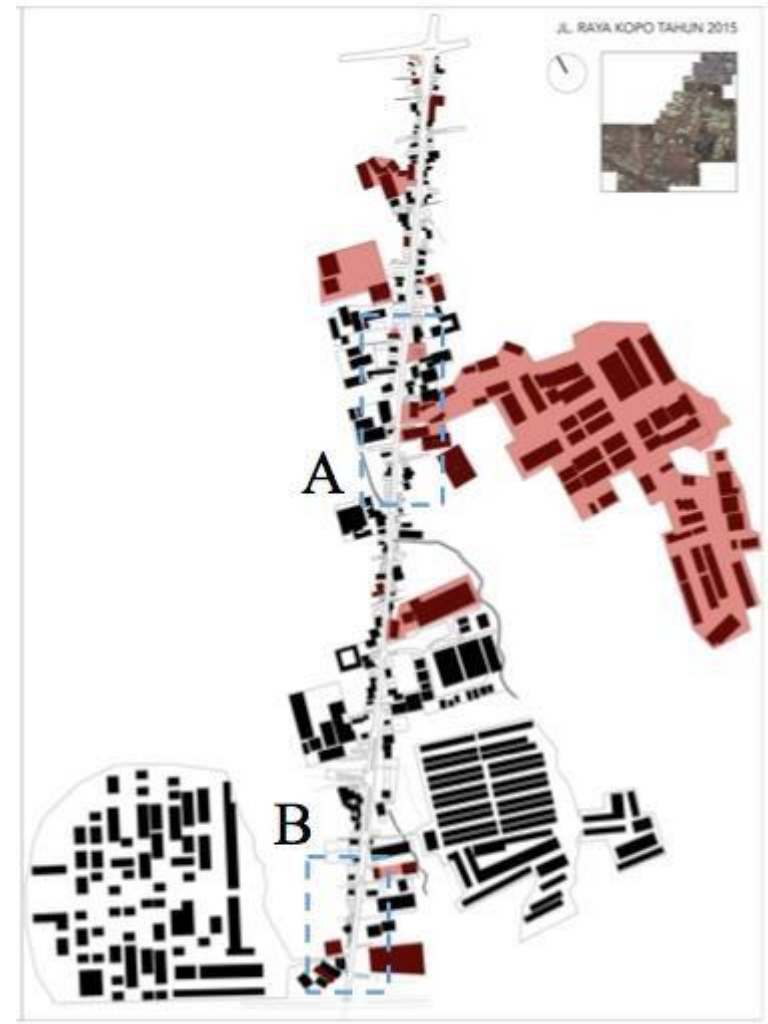

Figur 9. Segmen J1. Raya Kopo yang paling berkembang

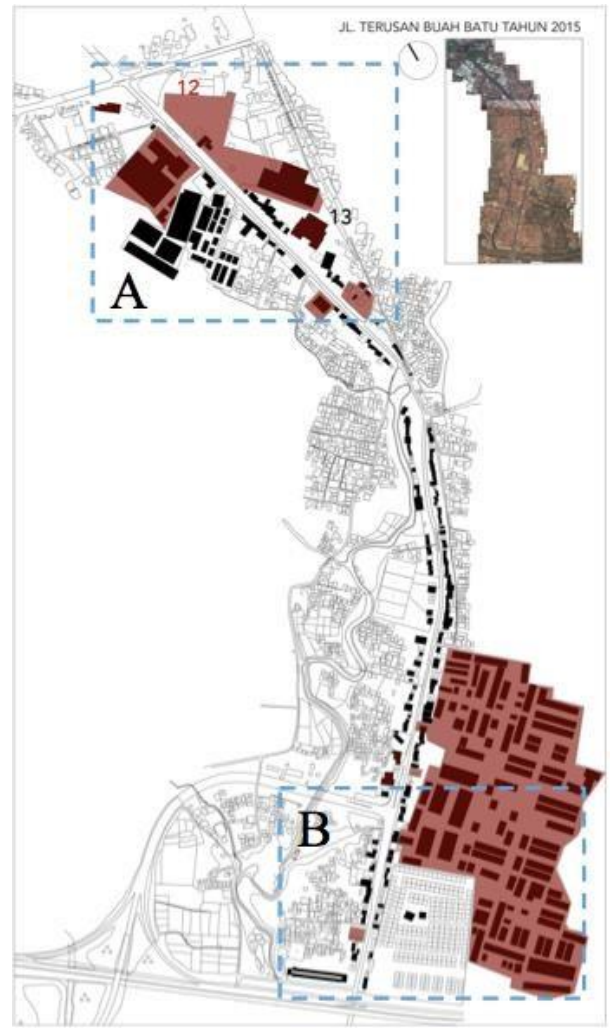

Figur 10. Segmen J1. Terusan Buah Batu yang paling berkembang

\subsection{KERAGAMAN}

Perubahan fungsi dan fisik spasial tersebut memicu terjadinya keragaman komponen fungsional (fungsi bangunan) dan komponen fisik spasial (ketinggian, tata massa, tipe bentuk dan luasan kapling). Secara fungsi pada kedua koridor jalan terdapat ragam fungsi yang berkembang dominan yaitu fungsi - fungsi komersial (perdagangan, jasa, dan mixed use) dan hunian serta industri. 

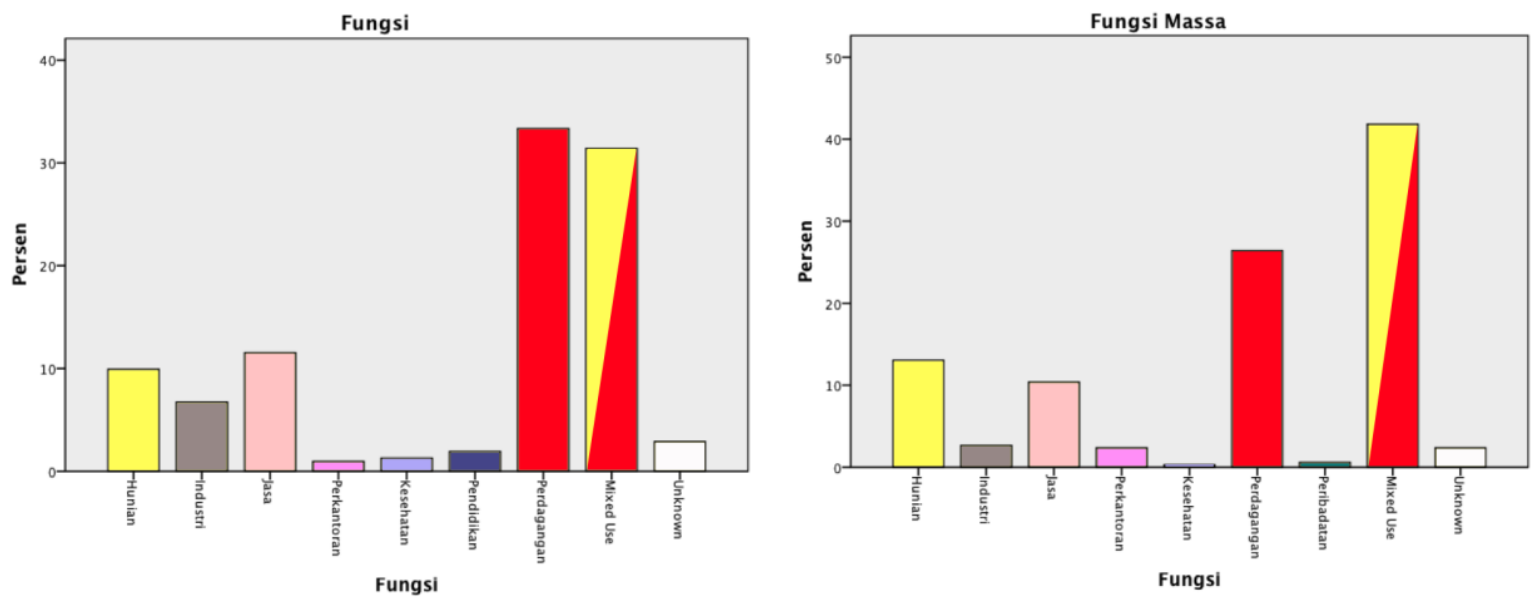

Figur 11. Ragam fungsi pada Jl. Raya Kopo

Figur 12. Ragam fungsi pada Jl. Ters. Buah Batu

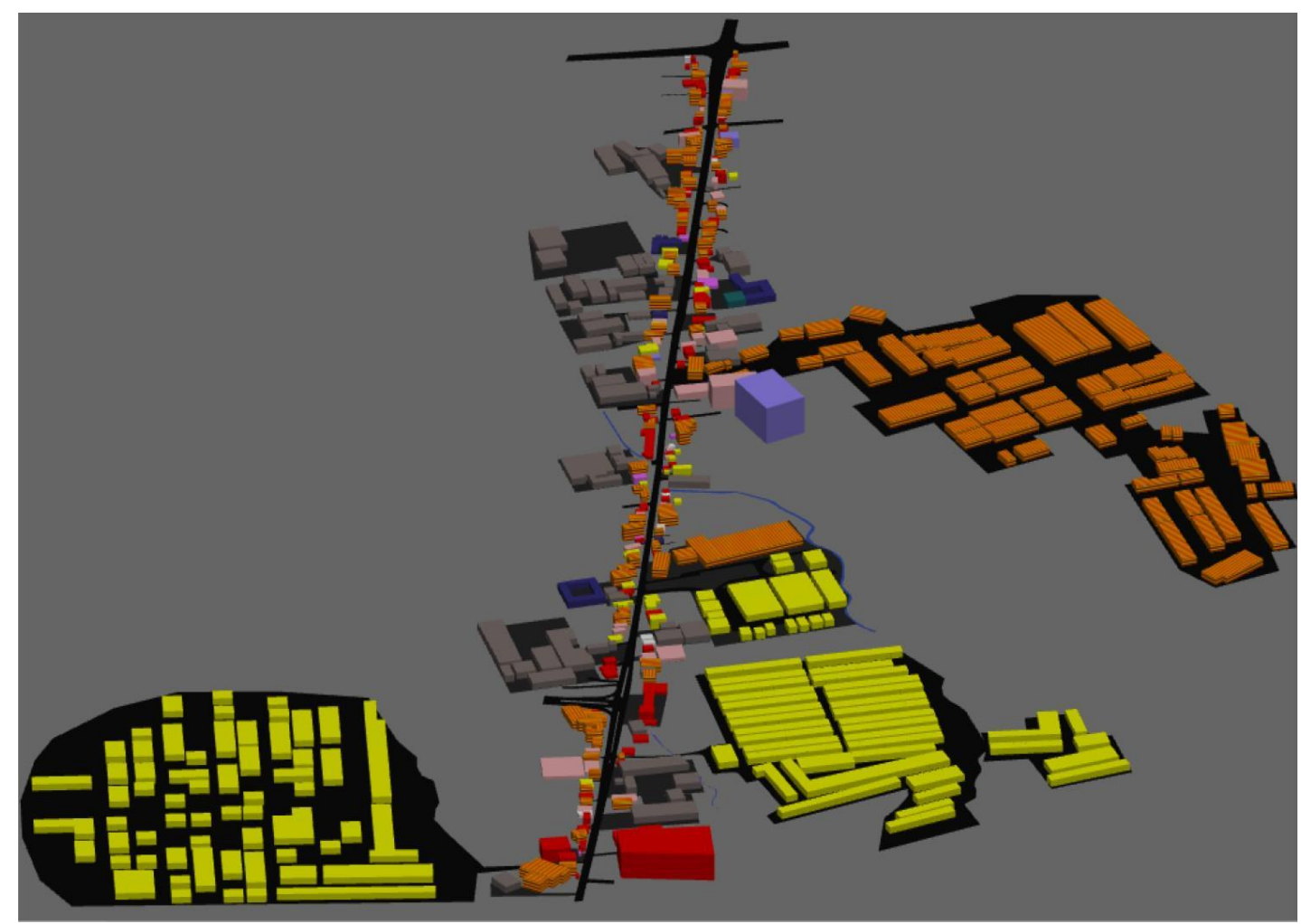

Figur 13. 3D massa pada Jl. Raya Kopo berdasarkan fungsi 


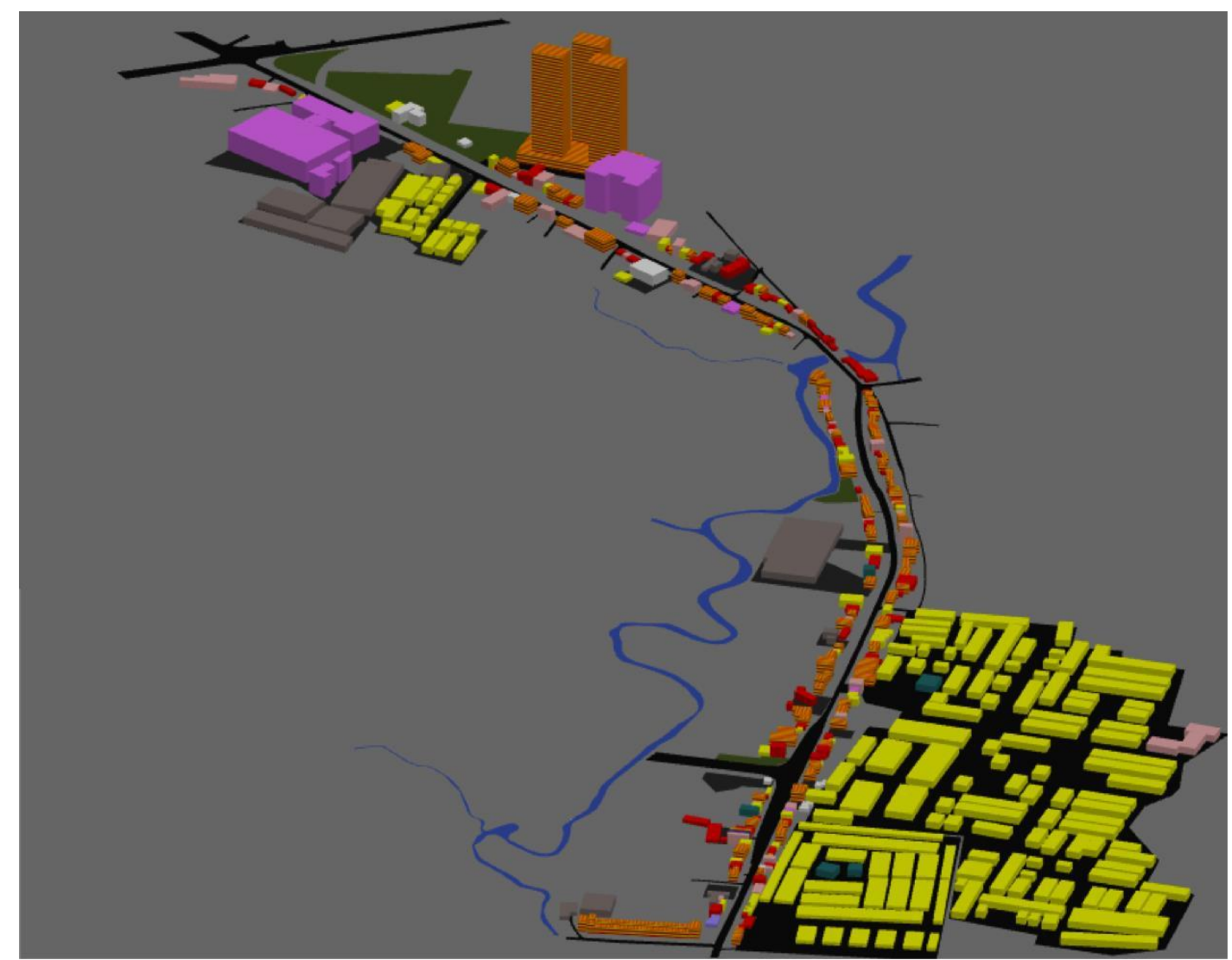

Figur 14. 3D massa pada Jl. Terusan Buah Batu berdasarkan fungsi

Dari keragaman fungsi tersebut muncul pula tipe komponen fisik spasial sebagai wadah fungsi yang lebih beragam. Secara umum keragaman fisik spasial dari aspek terkait massa, ketinggian masih di dominasi oleh bangunan tungga 1-2 lantai yang mempengaruhi skyline kawasan masih tergolong dominan rendah. Dari aspek terkait kapling masih di dominan kapling kecil dan mulai bermunculan kapling besar baik berupa kapling tinggal atau gabungan kapling kapling kecil. Adapun detailnya adalah sebagai berikut.
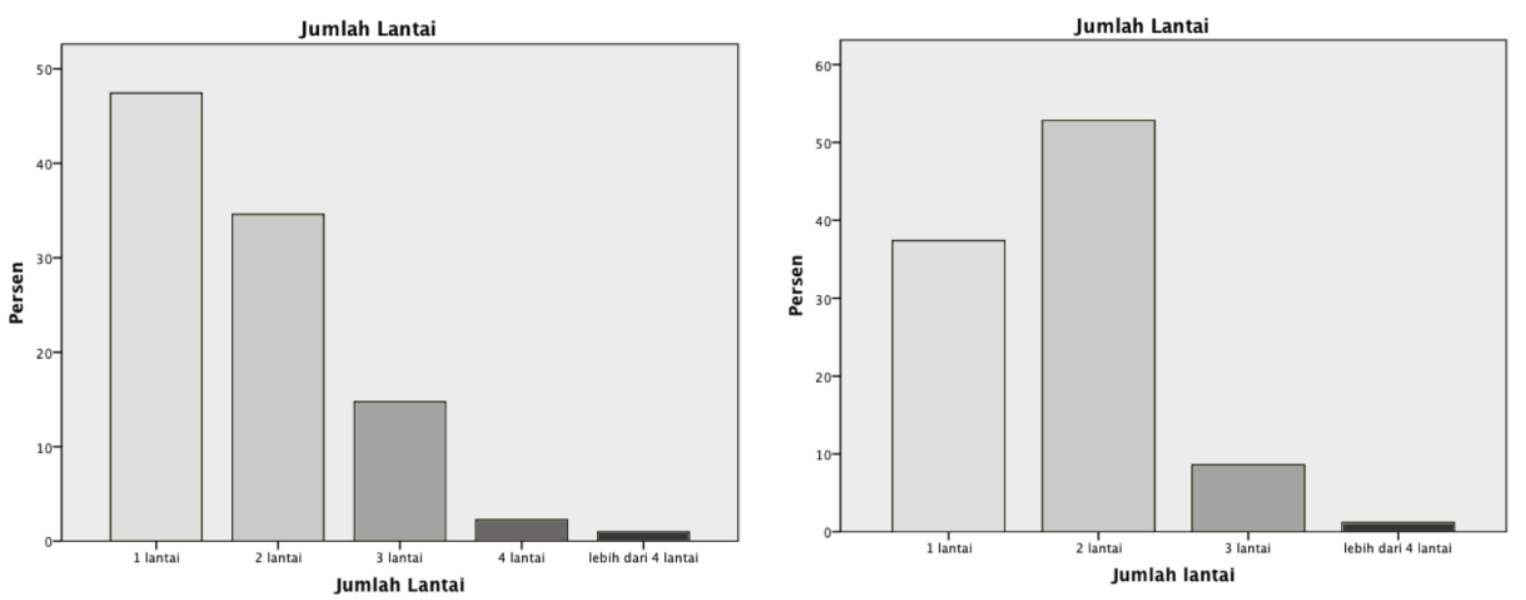

Figur 15. Ragam ketinggian pada J1. Raya Kopo

Figur 16. Ragam ketinggian pada J1. Ters. Buah Batu 

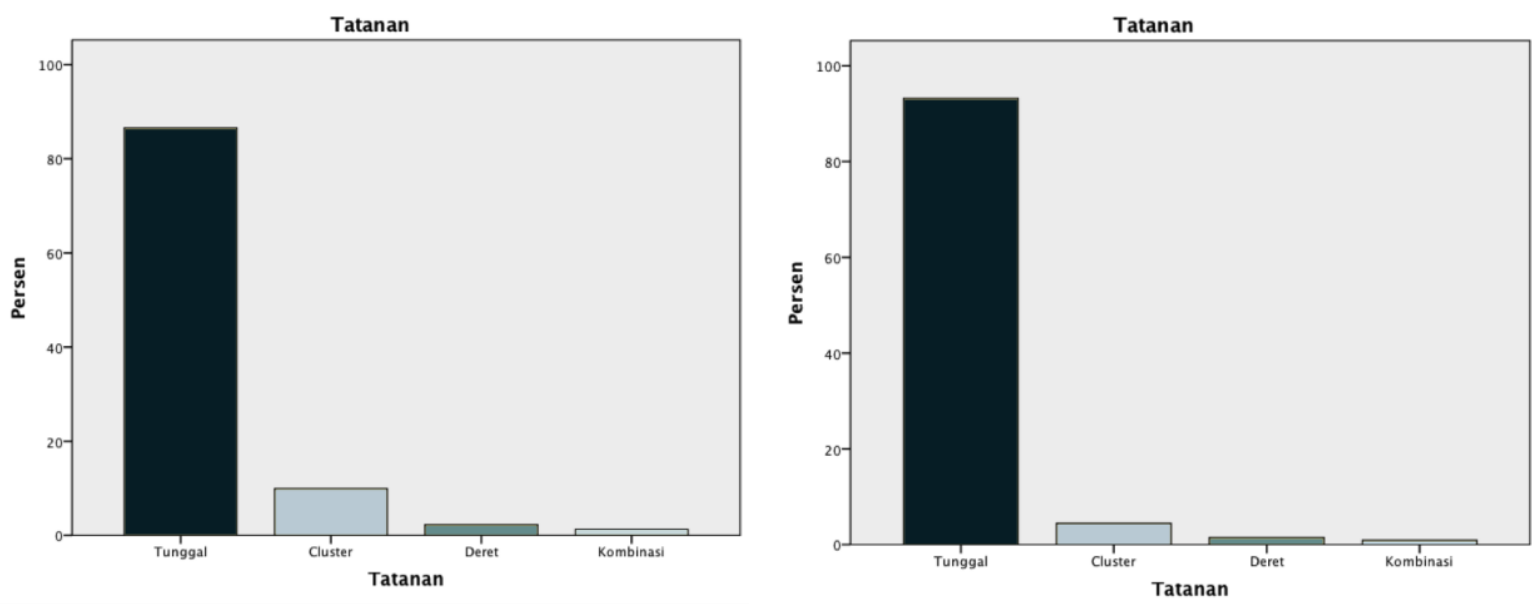

Figur 17. Ragam tata massa pada Jl. Raya Kopo

Figur 18. Ragam tata massa pada Jl. Ters. Buah Batu
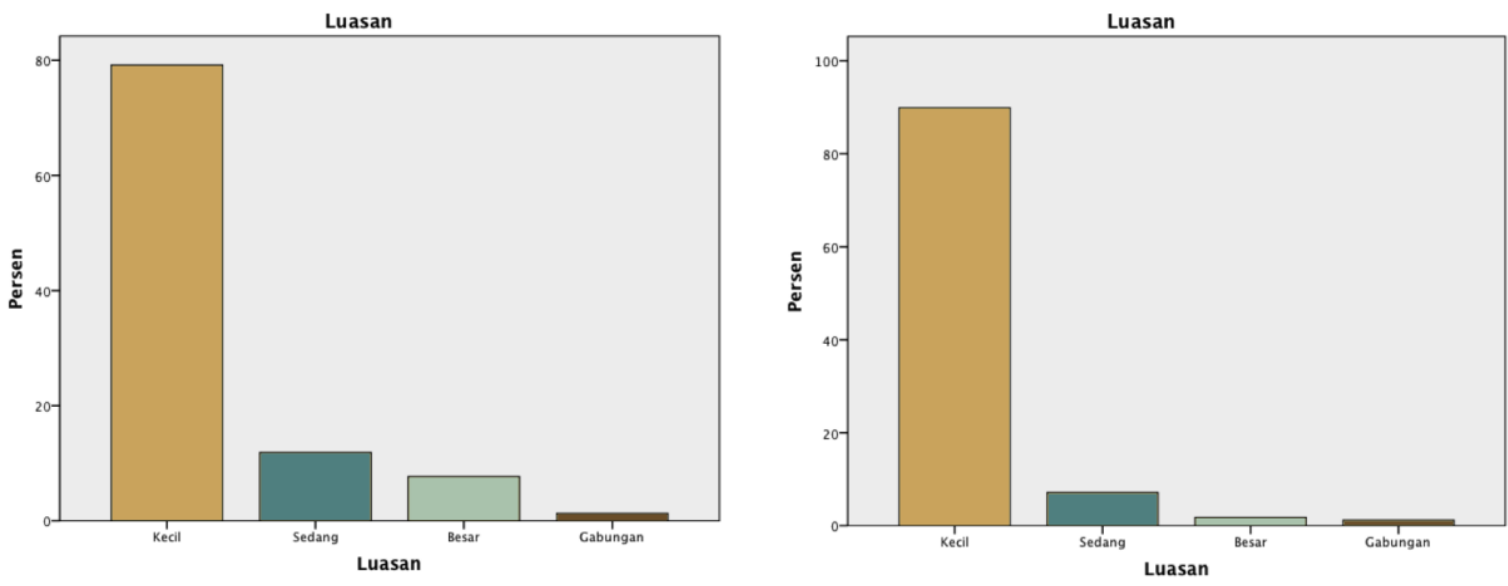

Figur 19. Ragam luas kapling pada J1. Raya Kopo

Figur 20. Ragam luas kapling pada Jl. Ters. Buah Batu
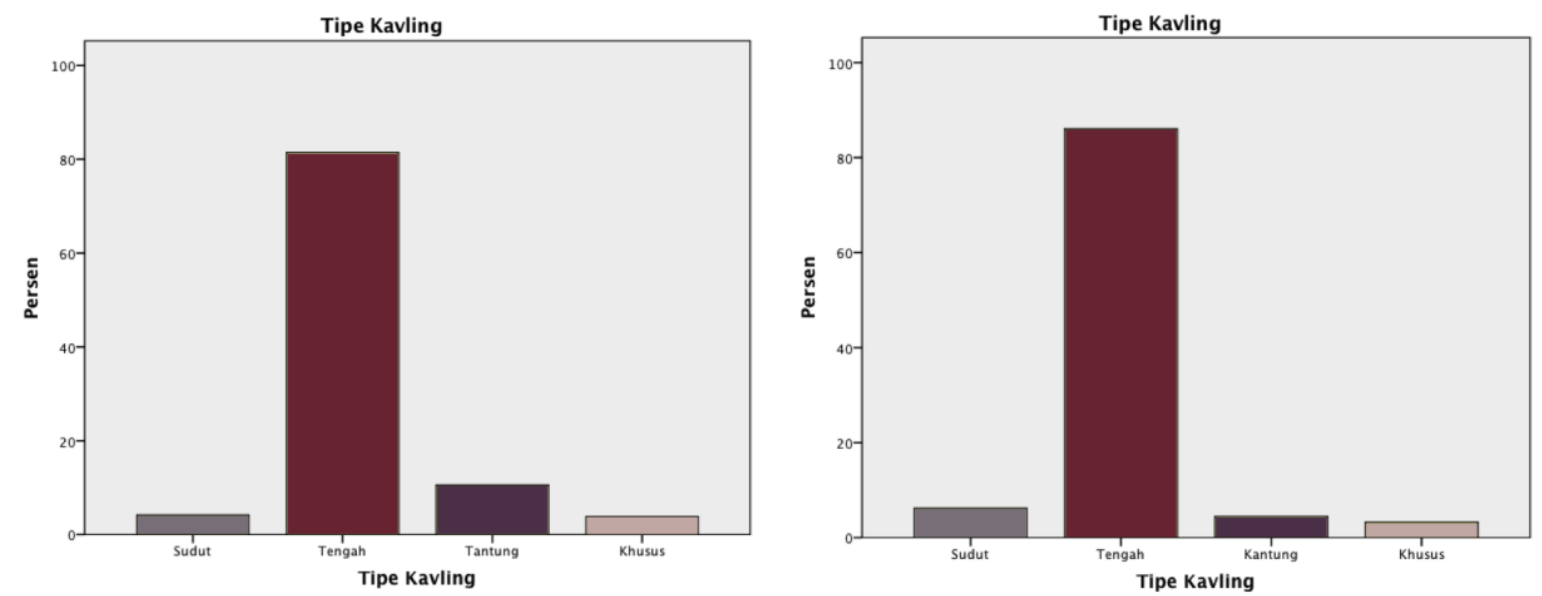

Figur 21. Ragam bentuk kapling pada Jl. Raya Kopo

Figur 22. Ragam bentuk kapling pada J1. Ters. Buah 


\subsection{HUBUNGAN ANTAR KOMPONEN KECENDERUNGAN}

Hubungan dan kecenderungan massa pertama ditinjau berdasarkan komponen fungsi yang ter bagi kedalam tiga tipe utaman yaitu Hunin, non hunian, dan mixed use. Berikut detail hubungan antar komponen beserta ragam tipe yang terjadi pada masing masing koridor jalan.

\subsubsection{JL. RAYA KOPO}

Pada Jl. Raya Kopo terdapat tujuh varian bedasarkan hubungan fungsi dan ketinggian. Dan elemen yang paling terkait adalah fungsi perdagangan dengan ketinggian 1 lantai.

\begin{tabular}{|c|c|c|c|c|c|c|}
\hline \multirow{2}{*}{ Fungsi } & \multicolumn{5}{|c|}{ Jumlah Lantai } & \multirow{2}{*}{ Tota } \\
\hline & $1 \mathrm{lt}$ & $2 \mathrm{It}$ & $3 \mathrm{It}$ & $4 \mathrm{lt}$ & $\geq 5 \mathrm{It}$ & \\
\hline Hunian & 17 & 10 & 4 & 0 & 0 & 31 \\
\hline Mixed Use & 0 & 59 & 36 & 3 & 0 & 98 \\
\hline Industri & 3 & 17 & 1 & 0 & 0 & 21 \\
\hline Jasa & 26 & 7 & 1 & 1 & 1 & 36 \\
\hline Perkantoran & 2 & 1 & 0 & 0 & 0 & 3 \\
\hline Kesehatan & 1 & 0 & 2 & 0 & 1 & 4 \\
\hline Pendidikan & 2 & 4 & 0 & 0 & 0 & 6 \\
\hline Perdagangan & 90 & 8 & 2 & 3 & 1 & 104 \\
\hline Unknown & 7 & 2 & 0 & 0 & 0 & 9 \\
\hline Total & 148 & 108 & 46 & 7 & 3 & 312 \\
\hline
\end{tabular}

Figur 23. Hubungan fungsi dan ketinggian pada Jl. Raya Kopo

Terdapat seupuh varian bedasarkan hubungan fungsi dan tata massa. Dan elemen yang paling terkait adalah fungsi perdagangan dengan tipe massa tunggal. 


\begin{tabular}{|l|c|c|c|c|c|}
\hline \multirow{2}{*}{ Fungsi } & \multicolumn{4}{|c|}{ Tata Massa dalam Kapling } & \multirow{2}{*}{ Total } \\
\cline { 2 - 5 } & Tunggal & Cluster & Deret & Kombinasi & \\
\hline Hunian & 27 & 0 & 1 & 3 & 31 \\
Mixed Use & 90 & 2 & 5 & 1 & 98 \\
\hline Industri & 5 & 16 & 0 & 0 & 21 \\
Jasa & 31 & 5 & 0 & 0 & 36 \\
Perkantoran & 3 & 0 & 0 & 0 & 3 \\
Kesehatan & 4 & 0 & 0 & 0 & 4 \\
Pendidikan & 3 & 3 & 0 & 0 & 6 \\
Perdagangan & 98 & 5 & 1 & 0 & 104 \\
\hline Unknown & 9 & 0 & 0 & 0 & 9 \\
\hline \multicolumn{1}{|r|}{ Total } & 270 & 31 & 7 & 4 & 312 \\
\hline
\end{tabular}

Figur 24. Hubungan fungsi dan tata massa pada Jl. Raya Kopo

Terdapat sepuluh varian bedasarkan hubungan fungsi dan luasan. Dan elemen yang paling terkait adalah fungsi perdagangan dengan luas kapling kecil.

\begin{tabular}{|c|c|c|c|c|c|}
\hline \multirow{2}{*}{ Fungsi } & \multicolumn{4}{|c|}{ Luasan } & \multirow{2}{*}{ Total } \\
\hline & Kecil & Sedang & Besar & Gabungan & \\
\hline Hunian & 22 & 6 & 0 & 3 & 31 \\
\hline Mixed Use & 83 & 12 & 2 & I & 98 \\
\hline Industri & 2 & 6 & 13 & 0 & 21 \\
\hline Jasa & 25 & 6 & 5 & 0 & 36 \\
\hline Perkantoran & 3 & 0 & 0 & 0 & 3 \\
\hline Keschatan & 2 & 1 & 1 & 0 & 4 \\
\hline Pendidikan & 3 & 1 & 2 & 0 & 6 \\
\hline Perdagangan & 98 & 5 & 1 & 0 & 104 \\
\hline Unknown & 9 & 0 & 0 & 0 & 9 \\
\hline Total & 247 & 37 & 24 & 4 & 312 \\
\hline
\end{tabular}

Figur 25. Hubungan fungsi dan luas kapling pada J1. Raya Kopo 
Terdapat sebelas varian bedasarkan hubungan fungsi dan tipe kapling. Dan elemen yang paling terkait adalah fungsi perdagangan dengan tipe kapling tepi jalan posisi tengah.

\begin{tabular}{|c|c|c|c|c|c|}
\hline \multirow{2}{*}{ Fungsi } & \multicolumn{4}{|c|}{ Tipe Kapling } & \multirow{2}{*}{ Total } \\
\hline & Sudut & Tengah & Kantung & Khusus & \\
\hline Hunian & 1 & 22 & 5 & 3 & 31 \\
\hline Mixed Use & 4 & 91 & 3 & 0 & 98 \\
\hline Industri & 1 & 3 & 15 & 2 & 21 \\
\hline Jasa & 1 & 27 & 4 & 4 & 36 \\
\hline Perkantoran & 0 & 3 & 0 & 0 & 3 \\
\hline Kesehatan & 0 & 3 & 1 & 0 & 4 \\
\hline Pendidikan & 0 & 3 & 2 & 1 & 6 \\
\hline Perdagangan & 6 & 93 & 3 & 2 & 104 \\
\hline Unknown & 0 & 9 & 0 & 0 & 9 \\
\hline Total & 13 & 254 & 33 & 12 & 312 \\
\hline
\end{tabular}

Figur 26. Hubungan fungsi dan ketinggian pada Jl. Raya Kopo

\subsubsection{JL. TERUSAN BUAH BATU}

Pada Jl. Terusan Buah Batu terdapat delapan varian bedasarkan hubungan fungsi dan ketinggian. Dan elemen yang paling terkait adalah fungsi mixed use dengan ketinggian 2 lantai. 


\begin{tabular}{|c|c|c|c|c|c|c|}
\hline \multirow{2}{*}{ Fungsi } & \multicolumn{5}{|c|}{ Jumlah Lantal } & \multirow{2}{*}{ Total } \\
\hline & $1 \mathrm{lt}$ & $2 \mathrm{It}$ & $31 \mathrm{t}$ & $4 \mathrm{lt}$ & $\geq 5 \mathrm{It}$ & \\
\hline Hunian & 21 & 22 & 1 & 0 & 0 & 44 \\
\hline Mixed Use & 1 & 121 & 18 & 0 & $\mathrm{I}$ & 141 \\
\hline Industri & 4 & 5 & 0 & 0 & 0 & 9 \\
\hline Jasa & 18 & 11 & 5 & 0 & 1 & 35 \\
\hline Perkantoran & 2 & 4 & 0 & 0 & 2 & 8 \\
\hline Kesehatan & 1 & 0 & 0 & 0 & 0 & 1 \\
\hline Perdagangan & 75 & 12 & 2 & 0 & 0 & 89 \\
\hline Peribadatan & 0 & 1 & 1 & 0 & 0 & 2 \\
\hline Unknown & 4 & 2 & 2 & 0 & 0 & 8 \\
\hline Total & 126 & 178 & 29 & 0 & 4 & 337 \\
\hline
\end{tabular}

Figur 27. Hubungan fungsi dan ketinggian pada Jl. Terusan Buah Batu

Terdapat sembilan varian bedasarkan hubungan fungsi dan tata massa. Dan elemen yang paling terkait adalah fungsi mixed use dengan tipe massa tunggal.

\begin{tabular}{|c|c|c|c|c|c|}
\hline \multirow{2}{*}{ Fungsi } & \multicolumn{4}{|c|}{ Tata Massa dalam Kapling } & \multirow{2}{*}{ Total } \\
\hline & Tunggal & Cluster & Deret & Kombinasi & \\
\hline Hunian & 40 & 1 & 0 & 3 & 44 \\
\hline Mixed Use & 138 & 1 & 2 & 0 & 141 \\
\hline Industri & 4 & 4 & 1 & 0 & 9 \\
\hline Jasa & 34 & 0 & 1 & 0 & 35 \\
\hline Perkantoran & 6 & 2 & 0 & 0 & 8 \\
\hline Keschatan & 1 & 0 & 0 & 0 & 1 \\
\hline Perdagangan & 83 & 5 & 1 & 0 & 89 \\
\hline Pribadatan & 2 & 0 & 0 & 0 & 2 \\
\hline Unknown & 6 & 2 & 0 & 0 & 8 \\
\hline Total & 314 & 15 & 5 & 3 & 337 \\
\hline
\end{tabular}

Figur 28. Hubungan fungsi dan tata massa pada Jl. Terusan Buah Batu 
Terdapat seupuh varian bedasarkan hubungan fungsi dan luasan. Dan elemen yang paling terkait adalah fungsi mixed use dengan luas kapling kecil.

\begin{tabular}{|c|c|c|c|c|c|}
\hline \multirow{2}{*}{ Fungsi } & \multicolumn{4}{|c|}{ Luasan } & \multirow{2}{*}{ Tota } \\
\hline & Kecil & Sedang & Besar & Gabungan & \\
\hline Hunian & 38 & 3 & 0 & 3 & 44 \\
\hline Mixed Use & 133 & 6 & 1 & I & 141 \\
\hline Industri & 5 & 1 & 3 & 0 & 9 \\
\hline Jasa & 30 & 5 & 0 & 0 & 35 \\
\hline Perkantoran & 6 & 0 & 2 & 0 & 8 \\
\hline Kesehatan & 1 & 0 & 0 & 0 & 1 \\
\hline Perdagangan & 82 & 7 & 0 & 0 & 89 \\
\hline Peribadatan & 2 & 0 & 0 & 0 & 2 \\
\hline Unknown & 6 & 2 & 0 & 0 & 8 \\
\hline Total & 303 & 24 & 6 & 4 & 337 \\
\hline
\end{tabular}

Figur 29. Hubungan fungsi dan luas kapling pada J1. Terusan Buah Batu

Terdapat duabelas varian bedasarkan hubungan fungsi dan tipe kapling. Dan elemen yang paling terkait adalah fungsi mixed use dengan tipe kapling tepi jalan posisi tengah. 


\begin{tabular}{|c|c|c|c|c|c|}
\hline \multirow{2}{*}{ Fungsi } & \multicolumn{4}{|c|}{ Tipe Kapling } & \multirow{2}{*}{ Total } \\
\hline & Sudut & Tengah & Kantung & Khusus & \\
\hline Hunian & 3 & 37 & 3 & 1 & 44 \\
\hline Mixed Use & 6 & 133 & 1 & 1 & 141 \\
\hline Industri & 1 & 1 & 6 & 1 & 9 \\
\hline Jasa & 4 & 28 & 1 & 2 & 35 \\
\hline Perkantoran & 0 & 6 & 1 & 1 & 8 \\
\hline Kesehatan & 0 & 1 & 0 & 0 & 1 \\
\hline Perdagangan & 6 & 78 & 3 & 2 & 89 \\
\hline Peribadatan & 0 & 2 & 0 & 0 & 2 \\
\hline Unknown & 1 & 4 & 0 & 3 & 8 \\
\hline Total & 21 & 290 & 15 & 11 & 337 \\
\hline
\end{tabular}

Figur 30. Hubungan fungsi dan ketinggian pada Jl. Terusan Buah Batu

\section{KESIMPULAN}

Koridor Jl. Raya Kopo berkembang sebagai koridor dengan dominasi fungsi perdadangan. Tata guna lahan pada kawasan tersebut telah bergeser dari yang dulunya merupakan kawasan hunian menajdi kawasan perdagangan. Tidak hanya komponen fungsional saja yang mengalami transformasi namun tatanan fisik spasial pada koridor Jl. Raya Kopo juga turut mengalami transformasi morfologi. Pada tahun 2015 dominasi dari komponen fisik spasialnya merupakan massa satu lantai dengan tata massa tunggal dalam kapling tepi jalan yang posisinya berada di tengah atau diapit oleh kapling lainnya dengan luasan kapling kecil yakni kurang dari $250 \mathrm{~m}^{2}$.

Sedangkan koridor Jl. Terusan Buah Batu berkembang menjadi koridor dengan dominasi fungsi komersial mixed use berupa ruko (rumah toko). Tata guna lahan pada kawasan tersebut telah bergeser dari yang dulunya merupakan kawasan hunian menajdi kawasan komersial. Koridor Jl. Terusan Buah Batu juga mengalami transformasi morfologi dengan dominasi dari komponen fisik spasialnya hampir serupa dengan yang terjadi di Jl. Raya Kopo hanya berbeda pada ketinggian bangunan yakni dominan massa dua lantai.

\begin{tabular}{|l|l|l|}
\hline \multirow{2}{*}{\multicolumn{1}{|c|}{ Hubungan }} & \multicolumn{2}{c|}{ Koridor } \\
\cline { 2 - 3 } & \multicolumn{1}{c|}{ Jl. Raya Kopo } & \multicolumn{1}{c|}{ Jl. Terusan Buah Batu } \\
\hline Fungsi dan Ketinggian & Perdagangan - 1 lantai & Mixed use - 2 lantai \\
\hline Fungsi dan Luasan & Perdagangan - kecil & Mixed use - Kecil \\
\hline Fungsi dan Tipe Kapling & Perdagangan - Tengah & Mixed use - Tengah \\
\hline
\end{tabular}




\begin{tabular}{|r|l|l|}
\hline $\begin{array}{l}\text { Fungsi dan Tata Massa dalam } \\
\text { Kapling }\end{array}$ & Perdagangan - Tunggal & Mixed use - Tunggal \\
\hline Sampel massa & & \\
\hline
\end{tabular}

Figur 31. Kecenderungan kawasan berdasarkan hubungan antar koponen

Dapat dikatakan bahwa kedua koridor tersebut mengalami transformasi morfologi yang serupa dalam lingkup fisik spasial dengan komponen ketinggian massa, tata massa, luasan dan tipe kapling, namun kecenderungan perkembangan fungsi kawasannya berbeda. Pada kawasan Jl. Raya Kopo cenderung fungsi perdagangan sedangakan pada Jl. Terusan Buah Batu cenderung fungsi mixed use.

\section{DAFTAR PUSTAKA}

Kunto, Haryoto. (1986). Semerbak Bunga di Bandung Raya. Bandung: PT. Granesia. Leupen, Bernard. et al. (1997). Design and Analysis. Rotterdam, Netherlands.

Rossi, Aldo. (1982). The Architecture of the City. London: The MIT Press.

Schulz, Norberg. (1984). Genius Loci Towards a Phenomenology of Architecture. New York: Rizzoli.

Shirvani, Hamid. (1985). The Urban Design Process. New York: Van Nostrand Reinhold Company.

Trancik, Roger. (1986). Finding Lost Space: The Theories of Urban Design. New York: Van Nostrand Reinhold Company.

Zahnd, Markus. (1986). Perancangan Kota secara Terpadu. Yogyakarta: Kanisius.

Dercon, Bruno. (1987). A Methodology for Architectural Description and Analysis: Brief Introduction in the Current Methodology of the Priangan Research Project.

Kubet, Vladimir. Et al. (2009). Interrelationship of Public Space and Built-in Corner Buildings Based on the Examples of Modernism in "Mali Liman" Area in Novi Sad. Serbia: University of Novi Sad.

Siregar, Sandi Aminuddin. (1990). Bandung - The Architecture of a City In Development. Katholieke Universiteit Leuven.

Dirjen Cipta Kaya, Draft Pedoman Penyusunan Rencana Tata Ruang Kawasa Perkotaan.

Pemerintah Kota Bandung. (1999/2000). Rencana Tata Ruang dan Wilayah Kota Bandung tahun 2001 - 2010. Bandung: Pemerintah Kota Bandung.

Pemerintah Kota Bandung. (2008). Peraturan Daerah Kota Bandung Tentang Rencana Tata Ruang dan Wilayah Kota Bandung tahun 2011 - 2031. Perda Kota Bandung No 03 Tahun 2006.

Pemerintah Kota Bandung (1992/1993). Rencana Detail Tata Ruang SWK Tegallega tahun 2010. Bandung: Pemerintah Kota Bandung.

Pemerintah Kota Bandung (1991/1992). Rencana Detail Tata Ruang SWK Gedebage tahun 2010. Bandung: Pemerintah Kota Bandung

Pemerintah Kota Bandung. (2014). Peraturan Daerah Kota Bandung Tentang Rencana Detail Tata Ruang Kota Bandung tahun 2015 -2035. Perda Kota Bandung No 10 Tahun 2015.

The City of Calgary Housing Guidelines. (2010). Land Use Planning and Policy. 